\title{
SHORTAGE OF GRADUATE TEACHERS OF SCIENCE
}

\begin{abstract}
$\mathrm{T}$ a conference called by the Federation of A British Industries in London, on January 14, to discuss the shortage of science teachers in schools, the president, Sir Harry Pilkington, said that the national interest demands that enough science teachers of quality, for all types of educational institution, shall teach and train students in the next fow years, so that our scientific and industrial leadership of the world over the next generation may resist challenges. Sir Harry declared that "industry will pay the price of leadership ; industry will invest in research, in development, in progress, in expansion and in science. Industry will try to face its obligations towards encouraging a greater national investment in education of this type".

The demand and supply of science teachers was examined by Sir Charles Morris, vice-chancellor of the University of Leeds, who said that in the 1920's and 1930's a really good graduate took a long time to get a public school or good grammar school job as a schoolmaster. In addition, in the 1920's and 1930 's, schoolmastering still attracted many able young men from the universities as a worth-while and gentlemanly life. For various reasons this seems to be no longer the case. There is to-day an effective economic demand for these men in research of all kinds, for general posts in industry and for university, college and school teaching.
\end{abstract}

The peak of this demand has not been seen either for research or for general industry. For university and school teachers the peak may well be reached between 1955 and 1960 .

Of the good academic men with fine personal qualities - of whom industry, research and the universities and schools all must have some-there are not enough to go round. Outside the universities and schools they are needed for fundamental and industrial research. A knowledge of the world and human nature is needed to provide the necessary flair and imagination for effective industrial research and for general posts in industry.

Sir Charles questioned whether the undergraduate body of scientists could be increased still further; it is not so easy as might be supposed. Most people agree that our present degree standards are pitched at about the right place, and that a policy of greatly increased admissions should not be advocated if it would lead to large numbers falling by the wayside at the end of the first year. The answer to the shortage of graduate teachers in science is that "we must make sure we are using well all the scientists we have in research and in industry and that we must somehow again make schoolmastering attractive to the young man of spirit, imagination and ambition".

How is this to be done? More and more people are coming to think that the benefits of salary and other differentials must go to good men who actually do the teaching as opposed to good organizers and administrators in the schools.

Dr. A. W. Barton, headmaster of the City of London School, stated that the problem is as much one of quality as of quantity. There are probably two hundred science posts in grammar schools vacant to-day, while both the academic and teaching ability of new science teachers is lower than it was in 1938 ; 10 per cent of the science teachers are either nongraduates or graduates in arts subjects. In the past ten years, 975 science teachers have left the schools for industry or administration. The shortage of science teachers is now beginning to be felt outside the schools. Two hundred places in university engineering departments were unfilled last October. A hospital medical school in London had 30 per cent of its places vacant at the same time. The science examiners for two of the largest examining boards reported that the majority of last year's General Certificate of Education candidates at Advanced Level passed by learning the work by heart instead of understanding it.

Dr. Barton suggested some possible remedies for this situation which is developing disastrously. A high-level conference representative of all the interests who both train and use scientists should be called to try to secure their fairer distribution. Governing bodies and headmasters should readily give facilities for research to able science teachers, who express a wish to undertake it, probably at a neighbouring university or technical college. Governing bodies should also seriously consider appointing more science teachers to headships of schools.

Science graduates should be deferred from national service if they go into school teaching. The Scientific Civil Service might second some of its scientific officers for, say, five years to the Ministry of Education for employment as school teachers. The universities could foster a rare combination of qualities by instituting general honours courses of three subjects, one of which should be an arts subject, such as English or history, and the others science subjects.

The industrial point of view was put by $\mathrm{Dr} . \mathbf{P}$. Dunsheath, chairman of the Federation of British Industries Education Committee, who said that the whole vast field of technology rests on the teaching of fundamental science; "anything which saps at the roots which lie in school science will inevitably have a disastrous effect on the growth of the plant which proliferates through industry".

There is considerable evidence, culminating in the latest report of the Advisory Council on Scientific Policy, to show that Great Britain is already behind some of its important industrial competitors in the application of science. To meet this situation we need not only a restoration of our former standards of science teaching but also a considerable advance on those standards. For the successful operation of an industrial concern there must be mutual respect between the staffs employed in the different sections covering research, development and production, which is fortified by the knowledge that all concerned possess a common understanding of the scientific principles involved.

Industry is more and more alive to the fact that the boy who leaves school at fifteen or sixteen and depends on subsequent part-time education suffers a disadvantage in his climb to the more responsible positions in industry. More boys who now leave at sixteen should remain at the grammar school up to the sixth form, and then take a formal part-time industry-based course in the science and practice of their technology. Such recruits will be very much hampered if they arrive without a good basis of mathematics and science on which to build their technology. Moreover, the very fact of strengthening the sixth form by keeping more boys in touch with 
academic life may influence a larger proportion to choose teaching as a vocation.

The question of the balance between teaching in arts and in science is of considerable importance. On the assumption that a good brain may be employed with equal profit in both scientific and arts subjects, the obvious solution is to deflect some of the arts students to science.

Many difficulties will be side-tracked if suggestions for bringing pressure on schools to change their outlook overnight, on local education authorities to increase their wages bill, or on teachers' unions to accept larger differentials, are avoided. All these may be desirable but, from a practical common-sense point of view, should be avoided at present because of their potential for delay. The course least prone to cause delay through vested interests would seem to be not to press for a change in the attitude of the schools but to give opportunities at university entrance for change-over to science and engineering and to provide suitable pre-entry courses for the purpose.

Although the problem is a complex one and there are many possible solutions, industry should not be asked to curtail its intake. Graduates are not being employed wastefully. The urgent need is a larger pool from which both teachers and industrial recruits can be drawn.

\section{NORTH OF ENGLAND EDUCATION CONFERENCE}

$\mathrm{A}^{\mathrm{T}}$

$T$ the North of England Education Conference, held at Morecambe on January 4, Mr. J. Chuter Ede gave the presidential address in which, reviewing the first ten years of the Education Act 1944, he said that the outstanding disappointment has been the failure to eliminate the competitive examination at the age of eleven. Inadequate effect has also been given to the principles, propounded in the White Paper which preceded the Act, of directing ability into the field where it would find its best realization, and of facilitating free interchange of pupils from one type of education to another. Other disappointments to Mr. Ede were the failure of all but nineteen of the 146 local authorities in England and Wales to submit the development plans based on the Act, which they had originally been required to do in six months, and the failure to correct the bias against craftsmanship and to do more than offer better opportunities for technical education at the secondary stage.

Mr. Ede's main plea was for unity among teachers, parents and authorities; but he offered a welcome warning against straining after uniformity and confusing this with unity. His remarks on technical education were taken up to some extent in a discussion on Tuesday morning which followed addresses by Mr. C. H. Wilson, principal of University College, Leicester, and Dr. P.F. R. Venables, principal of the Royal Technical College, Salford, on the place of the university and the technical college in higher technological education. Mr. Wilson began with a brief review of changes since the Barlow Committee in 1946 recommended the doubling of the output of university graduates in science and technology. While this was virtually accomplished by 1947 , all official statements continued to demand a greater output; but it is important to distinguish between graduates in all branches of technology and graduates in fundamental science, and between short-term and long-term requirements for either. On a short-term view, while the supply of scientists is adequate so far as industry is concerned, it is inadequate for schools ; but on a long-term view the supply of scientists seems to be reasonably adequate for some time ahead, though the best judges consider that further expansion in technology is still needed.

Discussing the adequacy of the present official policy, Mr. Wilson suggested that there may still be scope for the development of new departments of technology in the newer universities. In the long run the future of technology at the universities will be determined by four factors : the ability to forecast nationsl requirements for the different kinds of technologist; the growth in industry of $a_{0}$ much more generous view of the place of development research ; the supply by schools of students wishing to take technological degrees; and the development at universities of a consensus of opinion more congenial to the expansion of technological studies. Mr. Wilson said that he recognizes the difficulties and dangers to the academic health of the universities if any one faculty becomes out of balance, and he insisted that the universities have to face the larger questions of the place that technological studies should take in the life of the universities as a whole and the environment in which such studies are best conducted : technology is not necessarily best taught in the environment of a strongly materialistic philosophy.

Dr. Venables's paper was concerned more particularly with the technical college and with its contribution to technological education, which he distinguished carefully from technical education. Compared with the technical colleges, the universities are a small and relatively homogeneous group, and he argued that, in considering the contribution which the technical colleges could make to the expansion of higher technological education, quality not quantity of work is the essential criterion. Technological education he defined as for those who "maintain, manage and maximise industry", with special emphasis on the last two. Of the 422 institutions in England and Wales dealing to a greater or lesser degree with technical education, we need be concerned with no more than those 220 , the principals of which qualify for membership of the Association of Principals of Technical Institutions. Further, analysis of the work of these institutions, including the courses they offer, enrolments, recognition by professional bodies, their conduct of research and postgraduate facilities and regional requirements, have convinced Dr. Venables that it is essential to concentrate on some twelve to fifteen only of these institutions. Full university conditions could not possibly be created even for 44 institutions, he said, let alone 220.

Dr. Venables argued realistically that the exhortations and provisions of the Ministry of Education - Circular No. 98 on Governance, No. 94 on Research, and No. 255 on Recognized Courses of Advanced. Technology do not suffice for the further development of major technical colleges. The increased grant of 75 per cent and the recognition associated with it should on no account be made to an institution the local authority of which has not granted it a properly constituted established governing body with full powers within an approved annual financial estimate. If the local authorities will not or cannot shoulder the financial responsibility involved in the present 